\title{
Enhancement of Customer Satisfaction through Emphasizing on Customer Relationship Management, Brand Equity \& Value Chain
}

\author{
P. Pinakapani, Ajatashatru Samal
}

\begin{abstract}
This study attempts to evaluate the determinants of the combination of tested models of brand equity, service value chain and customer relationship management particularly in selected banking services for enhancing the satisfaction of the customer. The conceptual framework of these individual tested models is developed to offer customer satisfaction and delightnes. The applied structure of these tested models is based upon the customer-based brand value, also known as brand resonance model which contains five determinants such as brand images, brand salience, brand performance, brand judgment and brand services, culture \& leadership, hassle free documentation \& internet / e-banking services. The customer relationship management models contain identification of perspective \& potential customer acquisitions, Product/service value proposition, Product/service portfolio analysis \& mutually beneficial CRM. The Correlations were conducted and strong positive correlation between brand equity \& customer relation management is observed. It can be seen that CRM model has highly influenced the customer satisfaction in banking sector. The multiple regression results indicate that the brand equity model, CRM and Value Chain model do have a significant influence in the customer satisfaction.
\end{abstract}

Keywords : Brand Equity, Brand resonance, Banking services Customer Relationship Management, Value Chain.

\section{INTRODUCTION}

In India, service sector contributes significantly to the economy with a structured banking system being its backbone. The Indian banking has evolved itself along with the changing times and customer needs. Earlier studies carried out in the banking domain has pointed out that necessary steps need to be taken by banks that can give utmost satisfaction to the customers. A study on few research works have established the significance of value chain and CRM in determining the loyalty of customers. By an extensive review of the available literature through proposed works, articles in newspaper, other significant writings, it is understood that

Manuscript received on February 10, 2020.

Revised Manuscript received on February 20, 2020.

Manuscript published on March 30, 2020.

* Correspondence Author

Dr. P. Pinakapani*, Department of Management studies, GITAM University, Hyderabad, India, Email: panipink1@gmail.com

Ajatashatru Samal, Department of Management studies, Research Scholar, VTU, Belagavi Email - ajatashatru7@gmail.com

(C) The Authors. Published by Blue Eyes Intelligence Engineering and Sciences Publication (BEIESP). This is an open access article under the CC BY-NC-ND license (http://creativecommons.org/licenses/by-nc-nd/4.0/) research works has distinguished customer desire, discernment and fulfillment. It is to be noted that academically, not many research works have been accomplished that considers supposition and perspective of individual staff in the banks. With the passage of time, there has been no effort in considering and clubbing of new factors that are detrimental to customer loyalty. In a nutshell, whatever are the current existing models, they have not considered the collaboration of three factors - Value Chain, CRM and Brand Equity.

\section{REVIEW OF LITERATURE}

Feldwick ,[1] An intersecting perspective of brand equity is to possibly assess a brand as an individual entity with financial characteristics. This happens when the brand is sold and included in an organization balance sheet as an asset. Further it is observed that brand equity is a measure of the strength of the customer's relation with brand. The author further states that brand equity is a result of the association and idea a customer has about the brand, which is an image that is set in the customers mind. . Dibbs, [2]in his study the customer relationship management on the bank's performance \& found that innovative advance are the changing the ideas of promoting channels \& modify how customer shops. Jain \& Dhar, [3] in their study about the determinates of customer relationship management viability in India. It was discovered in customer relationship management rose as a center business process for keeping it up \& improving the focus edge in present day business undertaking. Ashok and Kumar, [4] in their exact investigation on satisfaction of customers with selected bank offices features that banks are the store of the world, the operational hubs of financial matters and indicators of country's property. They sat the cost of holding a customer is one-tenth when contrasted and the cost of acquiring a new one. Banks do offer tangible service yet that can't satisfy the customers, who in reality require in tangible service which could be experienced like conduct and productivity of staff, speed of transactions and the feeling. Saurabhi Chaturuedi and Rishnu Roy, [5] in their article clarifies Customer Relationship Management as an intelligent, customized and applicable communication with customers to create and maintain relationships. CRM is most critical in seeing long term customers, whom can be held. Technology is utilized by companies to attract in and retain customers effectively for the most extreme corporate development and benefit. CRM isn't a technology thing, however technology is basic in making it effective, CRM is business logic. 


\section{Enhancement of Customer Satisfaction through Emphasizing on Customer Relationship Management, Brand Equity \& Value Chain}

Sharma, Himani,[6] This examination paper is about the banker's points of view on e-banking activities exercises of respondents, effect of e- banking activities and promotional measures utilized by banks to aware e- banking. The overview data in this research utilized as a part of this questionnaire are gathered through a survey in Northern area of India by administering to 192 bankers. The enquiry uncovers that customers for the most part utilize e-banking benefits on influence of bankers. The bankers are persuaded that e-banking helps in enhancing the relationship amongst bankers and customers and that it would bring patent improvement in the overall performance of banks. Krishnamoorthy, V, R. Srinivasan, [7] Internet Banking is a tool for Customer Relationship Management - A Study on Customer Perspective", This examination expects to throw light on client perception on internet banking which fills in as a device for Customer Relationship Management. This investigation obviously demonstrates that banks are facing difficulties in retaining their existing customers, for which it is possible that they have to come up with innovating, they have to create trust with their customers and maintain the relation with them

\section{RESEARCH METHODOLOGY}

\section{A. Statement of the Problem}

Indian banking sector, being one of the major revenue contributor and strong pillar in the economy, offer several services to its customers. Two principle aspects in service namely chain of services in sequential order and customer relations are practiced separately. However, there is only a few available studies on impact of brand on customer satisfaction. Many of the research works carried out have found the importance of value chain and practices of CRM in deriving customer satisfaction from in an independent way. From the review of earlier research studies carried out, thesis works, published journal articles, and other relevant sources of information it is seen that many gaps could be identified in the factors concerning customer expectations, perception and satisfaction. Along with the gaps, the works have least or no consideration for the views and opinion of the staff members serving the customers. However, with the passage of time, much effort in inclusion and clubbing of new factors that enhances customer satisfaction which could bring delight to customers has not taken place. This means no serious effort to club factors like value chain, CRM and brand equity in a model has taken place.

Hence the study focuses on the opinion and views of the bank executives where the combined application of the three factors Value Chain, CRM and Brand Equity is determined to be a research gap.

\section{B. Scope of the study}

Study was carried in Bangalore city during the period of October 2019 - December 2019. The study may cover several other factors which influence the satisfaction of the customers. The study may also spot new opportunities and methods to design new services in banking.

\section{Objectives}

1. To examine and develop the Value Chain, CRM and Brand Equity model that enhances customer satisfaction.

2. To identify the impact of brand equity and value chain on customer satisfaction.

\section{Research Design}

The study has been designed to be empirical in nature and said to be of analytical and diagnostic type of research.

\section{E. Collection of Data}

Primary Data: A well-structured questionnaire is administered to 400 respondents selected randomly from various branches of identified banks.

Secondary Data: Journals, Textbooks related to Banking, Newspaper, reports from RBI and annual reports of selected banks.

\section{F. Selection of sample}

The essence of the study was to establish the influence of services value chain, customer relationship management practices in pleasing customers from selected banks in Bengaluru. With the passage of time, every national and international bank branch has made inroads into Bengaluru that offers number of services and different financial products to bring utmost satisfaction in the customers. From the review of literature, it is observed that every bank has defined their own CRM practices. 40 banks achieving high profit margin continuously for three years was chosen for the study. Simple random sampling technique is used to select the respondents from the chosen 40 banks in Bengaluru. From the sampling frame of 40 banks, 10 customers from each is selected which sums up to 400 customers.

\section{BRAND EQUITY, SERVICE VALUE CHAIN AND CRM MODEL}

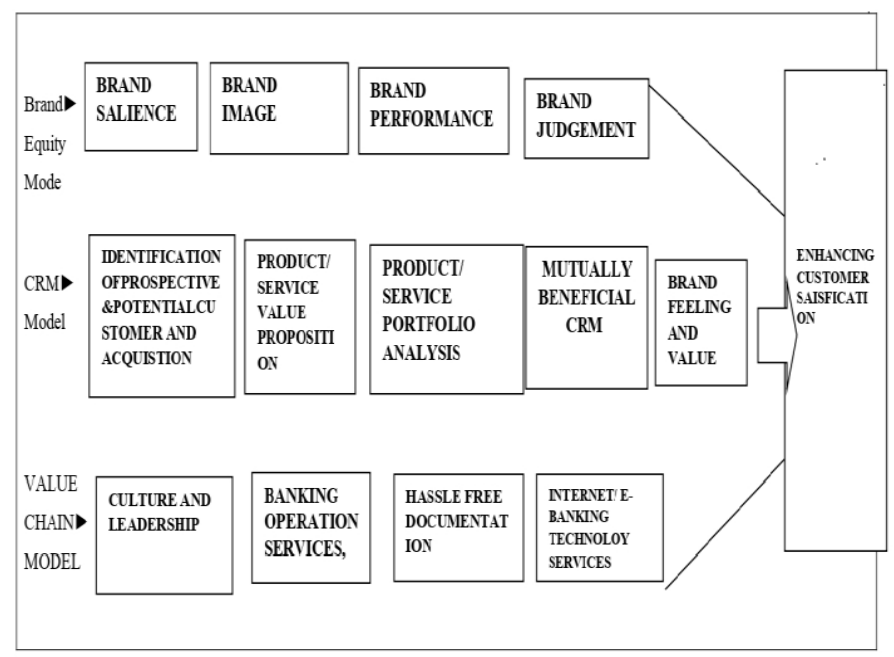




\section{ANALYSIS}

The data is represented in tabular form and is further subjected to analysis with statistical tool such as correlation analysis, regression analysis and ANOVA which are considered to be appropriate for the study.

\section{Test for reliability:}

The questionnaire consisting of 34 questions has been subjected to Cronbach Alpha reliability test which indicated a value of 0.951 . Since the value id more than 0.90 , it can be concluded that the questionnaire has high reliability.

Table1-Correlation \& Model Summary

\begin{tabular}{|c|c|c|c|c|c|}
\hline & & $\begin{array}{l}\text { Brand Equity } \\
\text { Model }\end{array}$ & CRM model & $\underset{\mathrm{L}}{\mathrm{VCHMODE}}$ & $\begin{array}{c}\text { Mean } \\
\text { customer } \\
\text { satisfaction }\end{array}$ \\
\hline \multirow{3}{*}{ Brand Equity Model } & Pearson Correlation & 1 & .808 & .781 & $.681^{\prime \prime}$ \\
\hline & Sig. (2-tailed) & & .000 & .000 & .000 \\
\hline & $\mathrm{N}$ & 400 & 400 & 400 & 400 \\
\hline \multirow{3}{*}{ CRM model } & Pearson Correlation & $.808^{\prime \prime}$ & 1 & $.859^{\circ}$ & $.819^{\prime \prime}$ \\
\hline & Sig. (2-tailed) & .000 & & .000 & .000 \\
\hline & $\mathrm{N}$ & 400 & 400 & 400 & 400 \\
\hline \multirow{3}{*}{ VCHMODEL } & Pearson Correlation & $.781^{\circ}$ & .859 & 1 & .796 \\
\hline & Sig. (2-tailed) & .000 & .000 & & .000 \\
\hline & $\mathrm{N}$ & 400 & 400 & 400 & 400 \\
\hline \multirow{3}{*}{$\begin{array}{l}\text { Mean customer } \\
\text { satisfaction }\end{array}$} & Pearson Correlation & $.681^{*}$ & $.819^{\prime \prime}$ & $.796^{\circ}$ & 1 \\
\hline & Sig. (2-tailed) & .000 & .000 & .000 & \\
\hline & $\mathrm{N}$ & 400 & 400 & 400 & 400 \\
\hline
\end{tabular}

\begin{tabular}{|l|c|r|r|ll|}
\hline Model & \multicolumn{1}{|c|}{ R } & R Square & $\begin{array}{c}\text { Adjusted } \mathrm{R} \\
\text { Square }\end{array}$ & \multicolumn{2}{|c|}{ Std. Error of the Estimate } \\
\hline 1 & $.839^{2}$ & .704 & .702 & & .36418 \\
\hline
\end{tabular}

\section{FINDINGS}

From the correlation table, it is evident that there is a higher degree of positive correlation between CRM and brand equity. High positive correlation exists between CRM model and customer satisfaction. A moderate level of correlation is observed between customer satisfaction, brand equity and value chain. It can be inferred from the above relationship that CRM model highly influences the customer satisfaction in banking sector. R-square value of 0.704 indicates that $70.4 \%$ of the variation in customer satisfaction is influenced by CRM model, value chain model and brand equity model. Beta co-efficient of 0.535 establishes the fact that CRM model influences the customer satisfaction in banking sector.

\section{CONCLUSION}

The research has identified that each factor namely brand equity, service value chain and customer relationship management are individually effective in any business context. Absence of any factor may yield satisfaction partially and sometimes not at all to the customer. However, the research emphasized the togetherness of the said factors certainly enhances the satisfaction of the customer. Especially, the impact of brand equity and value chain on the enhancement of customer satisfaction is evident. Therefore, every marketer may ensure that all the said three elements may be balanced while offering the product or service to the customer so that enhancement of satisfaction may turn the customer into brand loyal in turn to brand advocate.

\section{REFERENCES}

1. Feldwick $P(1996)$ " Do we really need " brand equity?.The Journal of Brand Management Vol4 No1 pp9-28

2. Dibb, Sally, (2001), -CRM: How to get beyond the hypel, Journal of Financial Services Marketing, Volume 6 (1), pp. 10-23.

3. Jain and Dhar, -Measuring Customer Relationship[2] Dibb, Sally, (2001), -CRM: How to get beyond the hypell, Journal of Financial Services Marketing, Volume 6 (1), pp. 10-23.

4. Ashok Kumar M, Sivakumar S (2006), -Customer Satisfaction in Banksl, PSG journal of Management Research, Volume 1, No 4, October-December, PP 101-110

5. Saurbhi Chaturvedi, Dr. Rishnu Roy (2008), Management Trends, Vol: 5, No: 1, Sep 2007 March

6. Himani Sharma(2011) Bankers Perspectives on E-banking, NJRIM, Vol:1, Issue No:1, June, 2011, pp. 71-85.

7. Krishnamoorthy, V., and Srinivasan, R. (2013). Impact of Customer Relationship Management on Loyalty in Indian Banking Sector- An Empirical Study. International Monthly Refereed Journal of Research In Management and Technology, 2,

8. Pinakapani.P \& Ajatshatru Samal (2017) Study on The Perception of Bank Executives on Customer relationship Management Practices in selected banks in Bengaluru; Publisher - International Journal of Management \& Social Sciences (IRJMSS), ISSN:2455-4553:

9. Ajatshatru Samal (2013) "A study on Competitive Indian Banking Industry with reference Pre-E-Banking and Post E-Banking, Publisher International Journal of Research in Commerce, IT \& Management, (IJRCM) Vol No-3, Issue No05(May), ISSN-2231-5756.

10. P Pinakapani and B Mohan Kumar ( 2019) "Effect of Extrinsic Cues on Perceived Quality by Confirming the Positive Effect of Perceived benefit" ": International Journal of Recent Technology and Engineering (IJRTE): ISSN:2277 - 3878: Vol-8 - Issue-3, September 2019; Page No: 5147-5151

11. B. Mohan kumar and P. Pinakapani ( 2019) "Identifying the Factors Influencing the Consumers Invariably To Make Brand Preferences among the Durables", International Journal of Innovative Technology and Exploring Engineering (IJITEE), ISSN: 2278-3075, Vol-X, Issue-X, July 2019

12. P. Pinakapani (2018) and Devi Prasad "Services Quality in Cosmetic Industry", The International Journal of Value Chain Management, ISSN (Print) 1741-5357 ISSN (online) 1741-5365, Page Nos : 346-355;

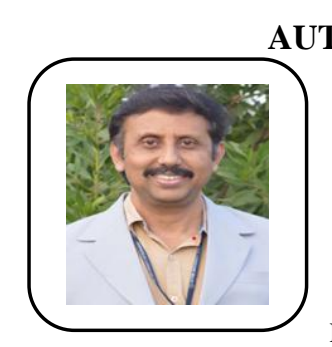

AUTHORS PROFILE

Dr. P. Pinakapani earned MBA, Ph.D from Andhra University campus, Visakhapatnam. He gained 27 years hand $s$ experience in teaching, research and academic administration. Prior to the teaching he worked as Marketing executive for 3 years. His areas of interest are Consumer Behaviour, Global Marketing, Business Planning, Strategic Mgt. He is presently working as a faculty in HBS, GITAM University, Hyderabad.

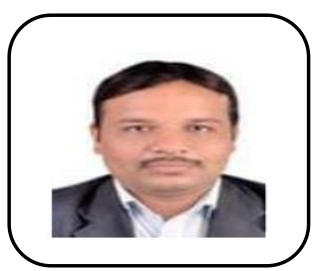

Prof. Ajatashatru Samal holds an MBA from BijuPatnaik University Technology, Orissa in the area of Marketing and Systems. Bhubaneswar. Presently pursuing Ph.D. in Marketing from V.T.U, Belagavi. He has 1 year of Industry experience and more than 15 years of teaching experience. He has presented and published many papers at National, International conference and Journals. His area of interests is Statistic of Management, Operation Research and Production \& Operation Management. Currently he is working as Associate Professor in Sambhram Academy of Management Studies. 